\title{
A Case Study of Multi Drug-Resistant Tuberculosis (MDR-TB), HIV and Diabetes Mellitus (Dm) Comorbidity: Triple Pathology; Challenges and Prospects
}

\section{Okorie Onuka', John Ahukanna', Chukwudi Okebaram ${ }^{2}$, Patrick Dakum ${ }^{3}$, Aderonke Agbaje ${ }^{3}$, Vivian Ibeziako ${ }^{3}$, Gidado Mustapha $^{4}$, Nkem Chukwueme ${ }^{4}$, Chux Anago ${ }^{5}$, Emperor Ubochioma ${ }^{6}$, Amarachi Okorie ${ }^{7}$, Odume Bethrand 8 , Nwafor Charles ${ }^{9}$}

\author{
${ }^{1}$ Abia State Ministry of Health, Umuahia, Nigeria \\ ${ }^{2}$ Department of Pharmacology, Abia State University, Okigwe, Nigeria \\ ${ }^{3}$ Institute of Human Virology, Abuja, Nigeria \\ ${ }^{4}$ Challenge KNCV, Abuja, Nigeria \\ ${ }^{5}$ Clinton Health Access Initiative, Abuja, Nigeria \\ ${ }^{6}$ National Tuberculosis and Leprosy Control Program, Abuja, Nigeria \\ ${ }^{7}$ School of Midwifery, Umuahia, Nigeria \\ ${ }^{8}$ Department of Family Medicine, National Hospital, Abuja, Nigeria \\ ${ }^{9}$ German Leprosy and Tuberculosis Relief Association, Enugu, Nigeria \\ Email: onphil200@yahoo.co.uk, c.okebaram.15@aberdeen.ac.uk, vibeziako@ihvnigeria.org, dilimcyn@yahoo.com, drchux@gmail.com, \\ emperorubochi@yahoo.com, amarachionuka34@yahoo.com, bethodume@gmail.com, Nigeria-cnnwafor660@gmail.com
}

How to cite this paper: Onuka, O., Ahukanna, J., Okebaram, C., Dakum, P., Agbaje, A., Ibeziako, V., Mustapha, G., Chukwueme, N., Anago, C., Ubochioma, E., Okorie, A., Bethrand, O. and Charles, N. (2017) A Case Study of Multi Drug-Resistant Tuberculosis (MDR-TB), HIV and Diabetes Mellitus (Dm) Comorbidity: Triple Pathology; Challenges and Prospects. Advances in Infectious Diseases, 7, 70-79.

https://doi.org/10.4236/aid.2017.73008

Received: April 11, 2017

Accepted: September 10, 2017

Published: September 13, 2017

\begin{abstract}
Tuberculosis (TB), diabetes mellitus and HIV co-morbidity is a rare and interrelated health condition with associated high morbidity and mortality especially in developing countries with high prevalence of TB. It has become an emerging concern to epidemiologists and TB control programs due to complexities in its control and management. Managing MDR-TB, DM and HIV comorbidity is challenging, with risk of unfavorable outcome; consequently, close monitoring is necessary. Individuals with weak immunity resulting from diseases such as uncontrolled Diabetes Mellitus (DM) and HIV have a higher risk of developing $\mathrm{TB}$ or progression from latent to active TB. We present a 65-year old known diabetic patient who presented to Royal Cross Hospital Ugwueke Abia State, Nigeria with a one-year history of recurrent productive cough with associated night sweats, low grade fever and marked weight loss. A diagnosis of drug-resistant TB with DM/HIV co-morbidity was made and co-managed by experts from the respective clinics and the State TB control program. The patient was declared cured ( 7 months consecutive negative cul-
\end{abstract}


Copyright $\odot 2017$ by authors and Scientific Research Publishing Inc. This work is licensed under the Creative Commons Attribution- NonCommercial International License (CC BY-NC 4.0). http://creativecommons.org/licenses/by-nc/4.0/

\section{Open Access}

tures each taken 30 days apart) after completing 20 months of conventional MDR-TB treatment. The patient showed remarkable clinical improvement including weight gain, good diabetic control and significant increase in CD4 (700 cells). Managing MDR-TB patients with diabetes and HIV is challenging, however, appropriate treatment, psychosocial support, adequate blood sugar control as well as monthly monitoring of patients with requisite investigations are vital in achieving good treatment outcome.

\section{Keywords}

Co-Morbidity-Diabetes-Multi Drug Resistant TB and HIV

\section{Introduction}

Tuberculosis (TB), HIV and diabetes mellitus (DM) co-morbidity is a rare occurrence. It is an emerging concern to epidemiologists and Tuberculosis control programs due to complexities in the management and side effects of the drugs [1]. They are interrelated health challenges with high morbidity and mortality especially in developing countries with high TB prevalence. According to [2], the three diseases were among the ten top killer diseases globally between 2000 and 2015. The bi-directional relationship between these three diseases has been established and validated by many scholars [3] [4]. Although the relationship between HIV and diabetes is unclear, it is argued that intake of anti-retroviral drugs predisposes to DM [5]. Managing MDR-TB/DM/HIV patient is challenging, with high risk of unfavorable outcomes; consequently, close monitoring of patient is necessary [6] [7] [8].

Tuberculosis is a chronic disease caused by mycobacterium tuberculosis (Mtb) and is transmitted by inhalation of droplet nuclei from an infected person when he or she coughs or sneezes [9]. TB characteristically affects the lungs but can affect other parts of the body as extra-pulmonary Tuberculosis. Drug-susceptible $\mathrm{TB}$ is treated with first line anti-TB drugs for six months. Multidrug-resistant TB (MDR-TB) is a form of drug-resistant TB in which Mtb is resistant to at least isoniazid (INH) and rifampin (RIF), the two most potent drugs used in the treatment of tuberculosis [10]. Extensively drug-resistant TB (XDR-TB) is a less common form of drug-resistant TB in which Mtb has changed enough to circumvent the two best antibiotics, INH and RIF plus any fluoroquinolone and at least one of the three injectable second-line drugs: amikacin, kanamycin or capreomycin [6] [10].

The emergence and spread of multidrug-resistant tuberculosis (MDR-TB) and extensively drug-resistant tuberculosis (XDR-TB) are major medical and public health problems threatening global health [1]. Globally, 480,000 people were estimated to have MDR-TB, 132,000 cases were notified in 2015 and 125,000 enrolled into care with $52 \%$ treatment success rate [11]. The global prevalence is $3.9 \%$ among new cases and, $21 \%$ among retreatment cases [11]. In Nigeria the 
MDR-TB prevalence survey conducted in 2012 revealed a prevalence of $2.9 \%$ among new cases and 14\% among retreatment cases [12]. Drug-resistance results from inadequate use of medicines used in the treatment of drug-susceptible TB, inappropriate regimen and poor compliance to treatment [1] [12].

Diabetes Mellitus is a chronic metabolic disease caused by inability of the pancreas to produce insulin or failure of the body to effectively make use of insulin resulting in sustained, elevated blood glucose levels [13]. The symptoms include increased urination, thirst and hunger with associated weight loss [8]. Diabetes is grouped into, type 1, type 2 and gestational diabetes. Type 2 DM occurs in adult populations [13].

Uncontrolled diabetes is associated with acute ketoacidosis and chronic complications, such as diabetic nephropathy, neuropathy, retinopathy, diabetic foot and cardiovascular problems [14] [15]. The development of diabetes is influenced by the interplay between metabolic and hereditary factors implicating physical inactivity, obesity, age and unhealthy diet as major predisposing factors [16]. The socioeconomic impact of DM is challenging as patients incur overwhelming high cost of treatment and may often lose their means of livelihood [13]. The interventions for DM include effective blood sugar control which is achieved by lifestyle changes such as good dietary control, physical activity and medical control using oral hypoglycemic agents or Insulin [13].

There is no contraindication in combining oral hypoglycemic and second line drugs for MDR-TB, however, higher doses of oral hypoglycemic drugs are required [6]. Prothionamide or Ethionamide may influence insulin level, more so creatinine and potassium levels need to be monitored closely during the use of these drugs [6]. In 2014, 422 million people were estimated to have DM which indicates a $290 \%$ increase when compared to 1980 data (108 million) [13]. More so, the prevalence rose dramatically from $4.7 \%$ in 1980 to $8.5 \%$ in 2014 which underpins that DM is on the increase [13]. Globally, 1.5 million people died of $\mathrm{DM}$ in 2012 [17]. In the African region, the prevalence rose from $3.1 \%$ in 1980 to $7.1 \%$ in 2014 [13].

Human Immunodeficiency Virus (HIV) belongs to the retrovirus family which attacks and weakens immune system leading to Acquired immune deficiency syndrome (AIDS) [1]. The major mode of transmission of the HIV infection is through unprotected sex, mother-to-child transmission, and use of contaminated sharp or piercing objects [18]. According to WHO [19] in 2015, 39 million people were living with HIV and two-third of the global target is in Africa (2.4 million). HIV has been fuelling TB incidence and $11 \%$ of incident cases of TB in 2015 were HIV co-infected [20].

\section{Literature Review}

The WHO publication opines that individuals with weak immune system resulting from diseases such as uncontrolled Diabetes Mellitus (DM) and HIV have increased risk of developing TB following a recent TB infection or progres- 
sion from latent to active TB disease [11]. Similarly, a study was conducted by [3] to determine the impact of DM on patients on anti-TB drugs in Iran. It was a case-controlled study, analyzed with SPSS and odd ratio computed scientifically. The findings revealed that $\mathrm{TB} / \mathrm{DM}$ co-infection has a greater risk of developing drug resistant TB. More so, the multivariate analysis of variables revealed that history of contact with index TB case is a major determinant.

In another vein, a study by [21] [22], conducted to ascertain Implications of the global increase of diabetes for tuberculosis control and association between HIV/AIDS and multi-drug resistance tuberculosis. It was systemic literature review and meta-analysis studies using public data bases. The findings proved that HIV is a key predisposing factor for TB disease with demonstrable evidence. More so, DM is becoming a potential risk to incidence of drug-resistant TB and difficulties in management. Similar studies were conducted to demonstrate association between TB/HIV coinfection MDR-TB and XDR-TB [4] [7]. The studies maintained that HIV remain a major driver of MDR-TB, XDR-TB and poor treatment outcome [4] [7].

A related study was piloted in South Africa to determine the implication of HIV on MDR-TB and XDR-TB epidemic [8]. The study portrayed a significant relationship between these diseases; however the increasing HIV/MDR-TB co-infection prevalence requires more funding and strategic collaboration to ensure effective control [8]. Globally, The WHO publication shows that $15 \%$ of TB cases are linked to uncontrolled DM with high relapse and mortality rates [11]. Likewise, a study to demonstrate increasing adverse drug reaction in Diabetes/MDR-TB comorbidity shows that DM increases the risk of developing TB and severe adverse drug reactions to second line anti-TB drugs especially nephrotoxicity and hepatotoxicity [23].

Another study by [24] stressed that among myriads of risk factors that favor TB infection and DM exerts great influences on pathogenesis of TB. Accordingly a study by [5] elucidated that HIV reduces sensitivity to AFB microscopy and delays early diagnosis.

A comparative study by [24] revealed delayed sputum conversion for TB/DM patients on anti-TB drugs underpinning the need for effective collaboration between National TB programs and DM clinics. Credibly, in a meta-analysis study by [25] to determine association between diabetes mellitus and multi-drug-resistant tuberculosis revealed that DM fast-tracks the development of Tuberculosis and complicates management [25].

\section{Case Report}

We present a 65 year old known diabetic mellitus patient who presented to Royal Cross Hospital Ugwueke Abia State, Nigeria with a year history of recurrent productive cough with associated night sweats, low grade fever and marked weight loss. The biodata of the patient is as indicated in Table 1.

Previous history revealed exposure to anti-TB drugs two years ago but was lost to follow up after three months of treatment. 
Table 1. Patient's demographic data.

\begin{tabular}{cc}
\hline Biodata & Values \\
\hline Age & 65 years \\
SEX & Female \\
Marital status & Widow \\
Occupation & Peasant Farmer \\
\hline
\end{tabular}

On physical examination, she was chronically ill looking, afebrile with generalized muscle wasting.

The following investigations were requested; sputum smear microscopy for Acid Fast Bacilli, Urinalysis, Fasting blood sugar and Xpert/MTB RIF assay. The results revealed presence of Mycobacterium tuberculosis bacilli in the sputum $(+++)$, resistance to Rifampicin and high Fasting blood sugar level of $352 \mathrm{mg} / \mathrm{dl}$ ) as well as glycosuria as noted in Table 1 . The State DR-TB consilium commenced the patient on community DR-TB treatment while she continued the HIV and diabetic treatment at Royal Cross Hospital Ugwueke. The following baseline investigations were conducted prior to commencement of DR-TB treatment; Sputum culture and Drug susceptibility testing (DST), CD4 count, pure tone audiometry, liver function test (LFT), serum electrolyte, Urea and creatinine, (S/E/U/C), thyroid function test (TSH), Full blood count (FBC), rapid HIV test and chest $\mathrm{x}$-ray.

The results of baseline sputum culture and DST revealed significant growth of mycobacterium TB that was resistant to Isoniazid and Rifampicin (MDR-TB). The results of other baseline tests are as shown in Table 2.

The Patient was co-managed for MDR-TB using the conventional 20 month MDR-TB regimen (8 months of Capreomycin $1 \mathrm{gm}(\mathrm{Km})$ Levofloxacin $750 \mathrm{mg}$ (Lfx) prothionamide (Pto) Cycloserine (Cs), pyrazinamide (Z), Ethambutol (E) + 12 Lfx, Eto, Cs, Z, E; anti-Retroviral drugs (Tenofovir 300 mg(TDF), Lamivudine $300 \mathrm{mg}$ (3TC), Efavirenz $600 \mathrm{mg}$ (EFV) and hypoglycemic drugs (Glibenclamide $5 \mathrm{mg}$ and metformin $1000 \mathrm{mg}$ ) [6] [13]. The baseline pure tone audiometry result showed left mild hearing loss and consequently, Capreomycin was used in place of Kanamycin. The patient tolerated the drugs well and exhibited good adherence throughout the duration of treatment. Clinical assessment, monitoring of sputum culture results, $\mathrm{AFB}, \mathrm{S} / \mathrm{E} / \mathrm{U} / \mathrm{C} / \mathrm{LFT}$, was done monthly throughout the intensive phase and two monthly during the continuation phase of the treatment.

The State TB control program in collaboration with the HIV program, Institute of Human Virology Nigeria (IHVN) and the hospital physicians managed and supported the patient with regular health education, monitoring of chemistry tests and other useful investigations. To ensure daily observed treatment (DOT) the State control program provided funds for daily transport to the clinics and monthly stipends for her upkeep. Managing this patient was associated with numerous challenges including: long duration of treatment, pill burden, 
Table 2. Baseline test results.

\begin{tabular}{|c|c|c|}
\hline Test & Value of ancillary investigations prior to treatment & Normal value \\
\hline Xpert/MTB Rif assay & MTB detected resistant to Rifampicin & MTB-Not detected. \\
\hline Leukocytes count & $13,000 \mathrm{c} / \mathrm{mcl}$ & $4000-11,000$ cells/mcl \\
\hline lymphocytes & $3.20 \times 10^{9} / 1$ & $(1.0-3.0) \times 10^{9} / 1(20 \%-40 \%)$ \\
\hline monocytes & $0.03 \times 10^{9} / 1$ & $(0.2-1.0) \times 10^{9} / 1(2 \%-10 \%)$ \\
\hline Basophils & $0.08 \times 10^{9} / 1$ & $(0.02-0.1) \times 10^{9} / 1(<1 \%-2 \%)$ \\
\hline eosinophils & $0.04 \times 10^{9} / 1$ & $(0.02-0.5) \times 10^{9} / 1(1 \%-6 \%)$ \\
\hline Neutrophils & $3.0 \times 10^{9} / 1$ & $(2.0-7.0) \times 10^{9} / 1(40 \%-80 \%)$ \\
\hline Red blood cells count & $5.01 \mathrm{million} / \mathrm{m}^{3}$ & $4.5-6.1 \mathrm{million} / \mathrm{m}^{3}$ \\
\hline Platelet counts & 190,000 cells & $150,000-440,000$ cells \\
\hline Sodium & $141 \mathrm{mEq} / \mathrm{L}$ & $135-145 \mathrm{mEq} / \mathrm{L}$ \\
\hline Chlorine & $102 \mathrm{mEq} / \mathrm{L}$ & $98-108 \mathrm{mEq} / \mathrm{L}$ \\
\hline Potassium & $3.8 \mathrm{mEq} / \mathrm{L}$ & $3.5-5.0 \mathrm{mEq} / \mathrm{L}$ \\
\hline Creatinine & $0.7 \mathrm{mg} / \mathrm{dl}$ & $0.6-1.2 \mathrm{mg} / \mathrm{dl}$ \\
\hline Urea & $27 \mathrm{ug} / \mathrm{dl}$ & $10-55 \mathrm{ug} / \mathrm{dl}$ \\
\hline FBS & $352 \mathrm{mg} / \mathrm{dl}$ & $70-120 \mathrm{mg} / \mathrm{dl}$ \\
\hline Total Bilirubin & $0.8 \mathrm{mg} / \mathrm{dl}$ & $0.3-1.0 \mathrm{mg} / \mathrm{dl}$ \\
\hline Conjugated bilirubin & $0.2 \mathrm{mg} / \mathrm{dl}$ & $<0.4 \mathrm{mg} / \mathrm{l}$ \\
\hline Alkaline Phosphates & $27 \mathrm{u} / \mathrm{l}$ & $9-35 u / 1$ \\
\hline AST & $10 \mathrm{u} / \mathrm{L}$ & up to $12 \mathrm{u} / 1$ \\
\hline ALT & $8 \mathrm{u} / 1$ & Up to $12 \mathrm{u} / 1$ \\
\hline Hemoglobin & $12 \mathrm{~g} / \mathrm{dl}$ & $12-15.5 \mathrm{~g} / \mathrm{dl}$ \\
\hline Acid fast bacilli test () & $3++$ & 0-Negative \\
\hline Sputum culture test () & $2++$ & 0 -Negative \\
\hline DST & Resistant to Isoniazid and Rifampicin & \\
\hline Weight & $55 \mathrm{~kg}$ & $>70 \mathrm{~kg}$ \\
\hline HIV result & HIV positive & HIV negative \\
\hline CD4 count & $<200$ cells & $500-1500$ cells \\
\hline TSH & $4.0 \mathrm{iu} / \mathrm{ml}$ & Hyperthyroidism $(0-0.5)$. Hypothyroidism $>4.1$ \\
\hline Pure tone Audiometry test & 30 DB mild bilateral Hearing loss & Hearing threshold, $25 \mathrm{Db}$ or less were regarded as normal \\
\hline Chest Xray & Cavitary lesions, increased hilar markings & Normal chest X-ray film \\
\hline
\end{tabular}

mild side effects, drug-drug interaction, fluctuation of blood sugar level, frequent hospitalization, discrimination and stigmatization.

Occasionally the patient complained of tinnitus, joint pain and chest pain.

The best practices adopted by the State TB control program include psychosocial support, monthly chemistry tests, pure tone audiometry, serial blood sugar monitoring as well as adequate hydration and management of side effects of the 
drugs. At the end of the 20 months of treatment the patient was cured of MDR-TB with consecutive negative culture tests for more than seven months and remarkable clinical progress with improved weight gain, adequate blood sugar control and significant increase in CD4 count as indicated in Table 3.

Table 3. Baseline and end of treatment test results.

\begin{tabular}{|c|c|c|c|}
\hline Test & $\begin{array}{c}\text { Value of ancillary investigations } \\
\text { prior to treatment }\end{array}$ & $\begin{array}{l}\text { Value of ancillary investigations } \\
\text { at the end of treatment }\end{array}$ & Normal value \\
\hline Xpert/MTB Rif assay & MTB detected resistant to Rifampicin & & MTB-Not detected. \\
\hline Leukocytes count & $13,000 \mathrm{c} / \mathrm{mcl}$ & $7000 \mathrm{c} / \mathrm{mcl}$ & $4000-11,000$ cells $/ \mathrm{mcl}$ \\
\hline Lymphocytes & $3.20 \times 10^{9} / 1$ & $3.60 \times 10^{9} / 1$ & $(1.0-3.0) \times 10^{9} / 1(20 \%-40 \%)$ \\
\hline Monocytes & $0.03 \times 10^{9} / 1$ & $0.04 \times 10^{9} / 1$ & $(0.2-1.0) \times 10^{9} / 1(2 \%-10 \%)$ \\
\hline Basophils & $0.08 \times 10^{9} / 1$ & $0.08 \times 10^{9} / 1$ & $(0.02-0.1) \times 10^{9} / 1(<1 \%-2 \%)$ \\
\hline eosinophils & $0.04 \times 10^{9} / 1$ & $0.045 \times 10^{9} / 1$ & $(0.02-0.5) \times 10^{9} / 1(1 \%-6 \%)$ \\
\hline Neutrophils & $3.0 \times 10^{9} / 1$ & $3.0 \times 10^{9} / 1$ & $(2.0-7.0) \times 10^{9} / 1(40 \%-80 \%)$ \\
\hline Red blood cells count & 5.01 million $/ \mathrm{m}^{3}$ & $5.01 \mathrm{million} / \mathrm{m}^{3}$ & $4.5-6.1 \mathrm{million} / \mathrm{m}^{3}$ \\
\hline Platelet counts & 190,000 cells & 160,000 cells & $150,000-440,000$ cells \\
\hline Sodium & $141 \mathrm{mEq} / \mathrm{L}$ & $149 \mathrm{Mmol} / \mathrm{L}$ & $135-145 \mathrm{~m} / \mathrm{Mol} / \mathrm{L}$ \\
\hline Chlorine & $102 \mathrm{mEq} / \mathrm{L}$ & $92 \mathrm{meq} / \mathrm{L}$ & $98-108 \mathrm{mEq} / \mathrm{L}$ \\
\hline Potassium & $3.8 \mathrm{mEq} / \mathrm{L}$ & $4.1 \mathrm{meq} / \mathrm{L}$ & $3.5-5.0 \mathrm{mEq} / \mathrm{L}$ \\
\hline Creatinine & $0.7 \mathrm{mg} / \mathrm{dl}$ & $0.7 \mathrm{mg} / \mathrm{dl}$ & $0.6-1.2 \mathrm{mg} / \mathrm{dl}$ \\
\hline Urea & $27 \mathrm{ug} / \mathrm{dl}$ & $22 \mathrm{ug} / \mathrm{dl}$ & $10-55 \mathrm{ug} / \mathrm{dl}$ \\
\hline Total Bilirubin & $0.8 \mathrm{mg} / \mathrm{dl}$ & 9.2 & $0.3-1.0 \mathrm{mg} / \mathrm{dl}$ \\
\hline Conjugated bilirubin & $0.2 \mathrm{mg} / \mathrm{dl}$ & $0.2 \mathrm{mg} / \mathrm{l}$ & $<0.4 \mathrm{mg} / \mathrm{l}$ \\
\hline Alkaline Phosphates & $27 \mathrm{u} / \mathrm{l}$ & $26 \mathrm{u} / \mathrm{l}$ & $9-35 u / 1$ \\
\hline AST & $10 \mathrm{u} / \mathrm{L}$ & $18.1 \mathrm{u} / 1$ & up to $12 \mathrm{u} / 1$ \\
\hline ALT & $8 \mathrm{u} / \mathrm{l}$ & $9.5 \mathrm{u} / 1$ & Up to $12 \mathrm{u} / 1$ \\
\hline FBS & $352 \mathrm{mg} / \mathrm{dl}$ & $110 \mathrm{mg} / \mathrm{dl}$ & $70-120 \mathrm{mg} / \mathrm{dl}$ \\
\hline Hemoglobin & $12 \mathrm{~g} / \mathrm{dl}$ & $14 \mathrm{~g} / \mathrm{dl}$ & $12-15.5 \mathrm{~g} / \mathrm{dl}$ \\
\hline Acid fast bacilli test () & $3++$ & 0 & 0 - Negative \\
\hline Sputum culture test () & $2++$ & 0 & 0 - Negative \\
\hline DST & Resistant to Isonizid and Rifampicin & & \\
\hline Weight & $55 \mathrm{~kg}$ & $87 \mathrm{~kg}$ & $>70 \mathrm{~kg}$ \\
\hline HIV result & HIV positive & HIV positive & HIV negative \\
\hline CD4 count & $<200$ cells & 700 cells & $500-1500$ cells \\
\hline TSH & $4.0 \mathrm{iu} / \mathrm{ml}$ & $4.0 \mathrm{iu} / \mathrm{ml}$ & $\begin{array}{c}\text { Hyperthyroidism }(0-0.5) . \\
\text { Hypothyroidism }>4.1\end{array}$ \\
\hline Pure tone Audiometry test & 30 DB mild bilateral Hearing loss & 35 mild bilateral hearing loss. & $\begin{array}{l}\text { Hearing threshold, } 25 \mathrm{Db} \text { or } \\
\text { less were regarded as normal }\end{array}$ \\
\hline Chest $\mathrm{x}$ ray & Cavitary lesions, increased hilar markings & & Normal chest X-ray films. \\
\hline
\end{tabular}


The patient is clinically stable; the final outcome of the MDR-TB treatment will be accessed by the $36^{\text {th }}$ month of treatment.

\section{Prospects/Discussion}

The treatment of this triple pathology causes changes in normal hepatic enzymes induction and drug-drug interactions [26]. Almost all licensed antiretroviral drugs (ARVs) have association with hepatotoxicity (elevated liver enzymes) and constitute the common antiretroviral drug-related liver injury (ARLI) [27]. The recovery of this patient points to a profound difference between the downregulation of systemic inflammatory response (SIRS) and upregulation of compensatory anti-inflammatory response (CARS). This interplay between SIRS and CARS determines whether the disease state will progress to much more severe outcomes [28] [29].

In this index case, there must have been a prominent factor that occasioned outstanding recovery and recession of signs and symptoms. It calls for a more granular inquest into the genetic and metabolomic profile of the patient.

Managing MDR-TB patients with diabetes mellitus and HIV is challenging, however, appropriate treatment, psychosocial support, adequate blood sugar control and monitoring of patients with required investigations are vital in achieving good treatment outcomes. Furthermore, improving the capacity of TB clinics to suspect and screen for DM and HIV will lead to early detection of the triple pathology in TB patients. Treatment for TB-DM-HIV comorbidity should be intensely implemented and proper care for diabetics provided to avert the risk of TB. Improving the knowledge of Diabetes prevention and care in the community will contribute to reduction in TB incidence. A multi-sectoral response is needed to ensure harmonized clinical management and address socioeconomic determinants of TB-DM-HIV co-morbidity.

\section{References}

[1] Srivastava, P.R. and Kumar, D. (2013) Multi Drug and Extensively Drug-Resistant TB (M/XDR-TB) Management: Current Issues' Clinical.

[2] WHO (2017a) Ten Top Causes of Disease. http://www.who.int/mediacentre/factsheets/fs310/en/

[3] Baghaei, P., Tabarsi, P., Javanmard, P., Farnia, P., Marjani, M., Moniri, A., Masjedi, M.R. and Velayati, A.A. (2016) Impact of Diabetes Mellitus on Tuberculosis Drug Resistance in New Cases of Tuberculosis. The Journal of Global Antimicrobial Resistance, 4, 1-4. https://doi.org/10.1016/j.jgar.2015.11.006

[4] Alexander, P.E. and De, P. (2007) The Emergence of Extensively Drug-Resistant Tuberculosis (TB): TB/HIV Coinfection, Multidrug-Resistant TB and the Resulting Public Health Threat from Extensively Drug-Resistant TB, globally and in Canada. Canadian Journal of Infectious Diseases and Medical, 18, 289-291. https://doi.org/10.1155/2007/986794

[5] Mythreyee, K.M. (2011) Tuberculosis HIV and Diabetes-Is It Time to Think Together. Journal of Microbiology Diagnosis, 1, e103.

[6] Ministry of Health Department of Health National Tuberculosis Programme (2013) 
Guidelines for the Management of Multidrug-Resistant Tuberculosis (MDR-TB) in Myanmar.

http://www.searo.who.int/myanmar/areas/GuidelinesforMDRTB.pdf

[7] Matteelli, A., Morgan D’Arcy, R., Sotgiu, G., Centis, R. and Migliori, G.B. (2009) Multidrug- and Extensively Drug-Resistant TB in Persons Living with HIV. Expert Review of Respiratory Medicine, 3, 245-254. https://doi.org/10.1586/ers.09.15

[8] Andrews, J.R., Shah, N.S., Gandhi, N., Moll, T. and Friedland, G. (2007) Multidrug-Resistant and Extensively Drug-Resistant Tuberculosis: Implications for the HIV Epidemic and Antiretroviral Therapy Rollout in South Africa. The Journal of Infectious Diseases, 196, S482-S490. https://doi.org/10.1086/521121

[9] WHO (2015) Tuberculosis and Diabetes. http://www.who.int/tb/publications/tb-diabetes-framework/en/

[10] CDC (2016a) Multi-Drug Resistant TB https://www.cdc.gov/tb/publications/factsheets/drtb/mdrtb.htm

[11] WHO (2016) MDR-TB FACT Sheet

[12] WHO (2012) Report of First National TB Prevalence Survey 2012. http://www.who.int/tb/publications/NigeriaReport_WEB_NEW.pdf

[13] Matteelli, A., Richardson, M.D.A., Sotgiu, G., Centis, R. and Migliori, G.B. (2009) Multidrug- and Extensively Drug-Resistant TB in Persons Living with HIV. Expert Review of Respiratory Medicine, 3, 245-254. https://doi.org/10.1586/ers.09.15

[14] WHO (2017) Commission on Ending Childhood Obesity. http://www.who.int/end-childhood-obesity/facts/en/

[15] Mayo Clinic (2017) Diabetes. http://www.mayoclinic.org/diseases-conditions/diabetes/basics/complications/CON $-20033091$

[16] CDC (2014) Diabetes 2014 Report Card. https://www.cdc.gov/diabetes/data/statistics/2014statisticsreport.html

[17] WHO (2016) Global Diabetes Report. http://apps.who.int/iris/bitstream/10665/204871/1/9789241565257_eng.pdf

[18] CDC (2016) HIV/AIDS. https://www.cdc.gov/hiv/basics/transmission.html

[19] WHO (2017) HIV/AIDS. http://www.who.int/mediacentre/factsheets/fs360/en/

[20] WHO (2016) Global Tuberculosis Report http://aidsdatahub.org/global-tuberculosis-report-2016-who-2016

[21] Ruslami, R., Aarnoutse, R.E., Alisjahbana, B., van der Ven, A.J. and van Crevel, R. (2010) Implications of the Global Increase of Diabetes for Tuberculosis Control and Patient Care. Tropical Medicine \& International Health, 15, 1289-1299. https://doi.org/10.1111/j.1365-3156.2010.02625.x

[22] Mesfin, Y.M., Hailemariam, D., Biadgilign, S. and Kibret, K.T. (2015) Association between HIV/AIDS and Multi-Drug Resistance Tuberculosis: A Systematic Review and Meta-Analysis. PLOS ONE, 9, e82235.

[23] Muñoz-Torrico, M., Caminero-Luna, J., Migliori, G.B., D’Ambrosio, L., Carrillo-Alduenda, J.L., Villareal-Velarde, H., Torres-Cruz, A., Flores-Vergara, H., Martínez-Mendoza, D., García-Sancho, C., Centis, R., Salazar-Lezama, M.Á. and Pérez-Padilla, R. (2016) Diabetes is Associated with Severe Adverse Events in Multidrug-Resistant Tuberculosis. Archivos de Bronconeumologia, 53, 245-250. 
https://doi.org/10.1016/j.arbr.2016.10.003

[24] Alejandro, G.G., Martin, M.A., Salvador, L.M., Marcelo, A.A., Dora, E.D., Guadalupe, M.H., Ángel, M.S., Martín, C.J. and Daniel, E.N. (2015) Diabetes and Other Risk Factors for Multi-drug Resistant Tuberculosis in a Mexican Population with Pulmonary Tuberculosis: Case Control Study. Archives of Medical Research, 46, 142-148. https://doi.org/10.1016/j.arcmed.2015.01.006

[25] Tegegne, B.S., Habtewold, T.D., Mengesha, M.M. and Burgerhof, J.G. (2017) Association between Diabetes Mellitus and Multi-Drug-Resistant Tuberculosis: A Protocol for a Systematic Review and Meta-Analysis. Systematic Reviews, 6, 6. https://doi.org/10.1186/s13643-017-0407-9

[26] Ruslami, R., Nijland, H.M., Adhiarta, I.G., Kariadi, S.H., Alisjahbana, B., Aarnoutse, R.E. and van Crevel, R. (2010) Pharmacokinetics of Antituberculosis Drugs in Pulmonary Tuberculosis Patients with Type 2 Diabetes. Antimicrobial Agents and Chemotherapy, 54, 1068-1074. https://doi.org/10.1128/AAC.00447-09

[27] Soriano, V., Puoti, M., Garcia-Gasco, P., Rockstroh, J.K., Benhamou, Y., Barreiro, P. and McGovern, B. (2008) Antiretroviral Drugs and Liver Injury. AIDS, 22, 1-3. https://doi.org/10.1097/QAD.0b013e3282f0e2fd

[28] Scheller, J., Chalaris, A., Schmidt-Arras, D. and Rose-John, S. (2011) The Pro-and Anti-Inflammatory Properties of the Cytokine Interleukin-6. Biochimica et Biophysica Acta (BBA)-Molecular Cell Research, 1813, 878-888. https://doi.org/10.1016/j.bbamcr.2011.01.034

[29] Buras, J.A., Holzmann, B. and Sitkovsky, M. (2005) Animal Models of Sepsis: Setting the Stage. Nature Reviews Drug Discovery, 4, 854-865.

https://doi.org/10.1038/nrd1854

Submit or recommend next manuscript to SCIRP and we will provide best service for you:

Accepting pre-submission inquiries through Email, Facebook, LinkedIn, Twitter, etc. A wide selection of journals (inclusive of 9 subjects, more than 200 journals)

Providing 24-hour high-quality service

User-friendly online submission system

Fair and swift peer-review system

Efficient typesetting and proofreading procedure

Display of the result of downloads and visits, as well as the number of cited articles

Maximum dissemination of your research work

Submit your manuscript at: http://papersubmission.scirp.org/

Or contact aid@scirp.org 